\title{
UREDINALES OF PORTO RICO BASED ON COLLECTIONS BY F. L. STEVENS ${ }^{1}$
}

\author{
J. C. Arthur
}

(Continued from page 255)

76. Aecidium abscedens sp. nov.

Pycnia epiphyllous, numerous on brownish spots 4-9 $\mathrm{mm}$. across, prominent, golden-yellow becoming dark-brown, hemispheric, subcuticular, I40-200 $\mu$ broad by about half as high.

Aecia hypophyllous, numerous in crowded groups, cupulate; peridia short, cylindric, $0 . \mathrm{I}-0.3 \mathrm{~mm}$. in diameter, soon open, coarsely lacerate, somewhat revolute, peridial cells colorless, somewhat overlapping, oblong, I I-I 6 by $20-37 \mu$, the outer wall I. $5-3 \mu$ thick, smooth, the inner wall slightly thicker, moderately verrucose; aeciospores broadly ellipsoid or glóboid, I8-2I by $20-27 \mu$ wall pale-yellow, thin, I-I.5 $\mu$, very closely and finely verrucose.

On Rubiaceae:

Randia aculeata L., Mayagüez, May 2, I125; Cataño, Nov.

3, 4534; Aguada, Nov. 22, 5089 (type).

A more recent collection, April 25, I9I4, comes from Martin Pena, P. R., made by Johnston \& Stevens 1886.

The species is apparently heteroecious. It is markedly different in both gross and microscopic appearance from the Mexican Aecidium pulverulentum Arth., which is the only other aecial form known on Randia, the publication of the host of the South American A. Randiae P. Henn. as Randia having been changed to Basanacantha (Hedwigia $43: 166$. 1904).

77. Aecidium Borreriae Pat.; Duss, Enum. Champ. Guad. 7. I903.

On Rubiaceae:

Hemidiodia ocimifolia (Willd.) K. Schum., Mayagüez, May 3, II 47 .

1 Continued from Mycologia 7: 255. I9r5. 
The species was described from material gathered by Pére Duss in Guadeloupe, and this is the second time it has been recorded.

78. Aecidium circumscriptum Schw.; Berk. \& Curt. Jour.

Phila. Acad. Sci. 2: 283. 1853 .

Aecidium Cissi Wint. Hedwigia 23: 168. 1884.

\section{On Cucurbitaceae:}

Cissus sicyoides L., Mayagüez, May I0, I912, Ibis, 2bis, April 30, 995b; San German, Jan. 19, 23a; Luguillo, March 21, 1912, 65; Corozal, Feb. 21, 404; Manati, Nov. 5, 4303; Aguado, Nov. 22, 5080; Aguadilla, Nov. 25, 5225; Jayome Alto, Dec. 3, 5680; Guayanilla, Nov. I3, 5912; Jayuya, Dec. I7, 5980; El Gigante near Adjuntas, Dec. I5, 6012; Cabo Rojo, Dec. 27, 6454; River junction below Utuado, Dec. 30, 6505, 6548; Preston's ranch near Naguabo, Dec. 3I, 6759.

The species on the same host has also been collected in Porto Rico by Underwood \& Griggs, at Rio Piedras, June, July, I9or, 238 , and by E. W. D. Holway, at San Juan, Jan. I9I I.

Similar specimens have been seen from Jamaica, collected by A. S. Hitchcock, Dec. I890, G. von Lagerheim, Dec. I892, F. S. Earle, Oct. 1902, L. M. Underwood, April, I903, and September, I906, 3302, and E. W. D. Holway, Feb. I9I 5.

In the Schweinitz herbarium at the Philadelphia Academy of Sciences there is an original unmounted packet inscribed in Schweinitz's handwriting "Aecidium circumscriptum. Surinam." This is undoubtedly type material. It contains five fragments, belonging originally to three or four leaves. The largest fragment is about 6 by $9 \mathrm{~cm}$., and two other of the fragments can be put together to show that one leaf was originally ovate, deeply cordate and entire, $9 \mathrm{~cm}$. broad by, $12 \mathrm{~cm}$. long. About $\mathrm{I} 50$ groups of aecia occur on the specimen altogether, in good representative condition. This material has been studied at the New York Botanical Garden and the host pronounced to be Cissus sicyoides, Mr. Percy Wilson vouching for the same.

The Schweinitz material in host and fungus agrees closely in 
appearance and microscopic detail with the Stevens' Porto Rican material, and with many other collections from other places, which have heretofore been given the Winterian name. The Schweinitz name, being much older, is therefore given preference.

79. Aecidium decoloratum Schw.; Berk. \& Curt. Jour. Phila. Acad. Sci. $2: 283$. $\quad 1853$.

Aecidium Clibadii Syd. Ann. Myc. I: 333. 1903.

On Carduaceae:

Clibadium erosum (Sw.) DC., Jajome Alto, Dec. 3, 5655 .

The type material in the Schweinitz collection at Philadelphia consists of the larger part of four or five leaves, which originally measured about 16 to $22 \mathrm{~cm}$. long and IO-I $2 \mathrm{~cm}$. wide. They bear numerous groups of aecia. The inscription in Schweinitz's handwriting reads, "Aecidium decoloratum-in foliis an Syng. -Surinam." A likeness was detected between these large composite leaves and those of the Stevens' collection. Through the kindness of the authorities of the Philadelphia Academy of Sciences, it was possible to submit the Schweinitz material to $\mathrm{Mr}$. Percy Wilson of the New York Bot. Garden, who readily ascertained the host to be Clibadium surinamense L., a common composite plant of Dutch Guiana.

80. Aecidium expansum Diet. Hedwigia 38: $258 . \quad$ i899.

On Carduaceae:

Mikania cordifolia (L. f.) Willd., Coamo Springs, Jan. I, 90; Mayagüez, April 30, 995a, May I, I061, May 2, I130, June I3, 2220, Oct. 31, 3894; Yauco, Oct. 3, 3126; Monte de Oro near Cayey, Dec. 3, 3742; Lares, Nov. 22, 4934, 4935; Jajome Alto, Dec. 3, 5758; River junction below Utuado, Dec. I7, 6069, Dec. 30, 6585, 6873.

Mikania sp., Villa Alba, Jan. 3, I35.

No original material of this species has been available for comparison, but the agreement of the Porto Rican material with the description of the Brazilian fungus is remarkably close, the only discrepancy being the slightly smaller spore measurements for 
the South American collection, which is well within the limits of laboratory variation.

The species shows a luxuriant and abundant development, and is doubtless heteroecious.

81. Aecidium Wedeliae Earle, Muhlenbergia i : i6. I90i.

On Carduaceae:

Wedelia trilobata (L.) Hitch. (W. carnosa Pers., Stemmodontia trilobata Small), Mayagüez, July 27, I9I2, 72, Jan. I5, 283, April 27, 835; Cabo Rojo, June II, 2184; Utuado, Nov. 8, 4595a, 4607; Maricao, Nov. I8, $4704 a$; St. Ana, Dec. 31, 669I; El Gigante near Adjuntas, Dec. I5, 80I0; without locality, Jan. I4, I9I4, $678 r$.

This form is very common in Porto Rico. Collections from the island have been examined from Mayagüez, by A. A. Heller 4580, and G. P. Clinton 54, April 1904, from Utuado by Underwood \& Griggs, June-July I90I, from San Juan and Santurce, by E. W. D. Holway, Jan. I9I I, from Trujillo Alto, by J. R. Johnston I042, August I9I3, and from Campo Alegre, by J. A. Stevenson 2475 , Dec. I9I 5 .

Although recorded from other West Indian islands the only specimen examined is from Jamaica, by E. W. D. Holway 213 , Feb. 1915.

It has been suggested by Dr. Stevens that this rust may be the aecial form of Puccinia canaliculata on Cyperus, which is known to produce aecia on Xanthium in the northern United States. The morphological characters favor the suggestion.

\section{ForM GeNUS UREDO}

Paraphyses absent, mostly forms belonging to Aecidiaceae, Nos. 82 to 98 .

Paraphyses present.

Free and peripheral, mostly forms belonging to Aecidiaceae, Nos. 99 to 104 . Imbricated to form a pseudoperidium, forms probably belonging to Uredinaceae, Nos. 105 to 108 .

United into a peridium, cellular above, belonging to Uredinaceae, No. rog. 
82. Uredo paspalicola P. Henn. Hedwigia 44: 57. 1905.

On Poaceae:

Paspalum conjugatum de Bary, Adjuntas, Nov. 22, 4966. This thin-walled, pale-spored rust, which is now reported for North America for the first time, has also been collected in Guatemala, on Paspalum Humboldtianum, Jan. II, 1915, by E. W. D. Holway 64 . The two collections agree closely with the type collection on $P$. conjugatum from Peru, as careful study shows.

83. Uredo Dichromenae Arth. Bull. Torrey Club 33: 3i. I906.

\section{On Cyperaceae:}

Dichromena ciliata Vahl, Mayagüez, April 30, 927.

Dichromena radicans Cham. \& Schl., Guayama, April 6, 847 .

The type specimen of the species was collected on D. ciliata, at Mayagüez, April, I904, by G. P. Clinton. The form was also collected in Jamaica by L. M. Underwood, May, I903, 2892.

The form is given for South America by Mayor in his list of Colombian Uredinales (Mém. Soc. Neuch. Sci. 5: 581. I913).

84. Uredo Fuirenae P. Henn. Hedwigia Beibl. 38: 70. 1899. On Cyperaceae:

Fuirena umbellata Rottb., Santurce, Jan. 22, 253; Aguas Buenas, Feb. 9, 300; Mayagüez, April 30, 920, Oct. 31, 3953; St. Catalina, Aug. 28, 2743; Cataño, Nov. 3, 453I. This rust was also gathered on the same host at Bayamon, P. R., Jan. I9II, by E. W. D. Holway, and in Cuba, Oct. I904, by Baker \& Wilson 2214, and March 1907, by F. S. Earle 652 .

The species was described from Brazil on $F$. umbellata, and it has been distributed from India, also on the same host. No teliospores have been found in connection with it. It differs strongly from the uredinia of the Fuirena rust in the southern United States, Puccinia Fuirenae Cooke, by having two pores, instead of three or four as in that species, and in other characters. 
85. Uredo Dioscoreae P. Henn. Hedwigia 35: 255. 1896.

On Dioscoreaceae:

Rajania cordata L., Bayamon, without date, 4162 ; Utuado,

Nov. 8, 4673; Jajome Alto, Dec. 3, 5658, 5757; El

Gigante near Adjuntas, Dec. 15, 5948; River junction below Utuado, Dec. I6, 6030; St. Ana, Dec. 31, 6687.

The only other collection of this rust from the West Indies known to the writer was made by E. W. D. Holway in Cuba, March, I903. The Holway collection is not on Rajania, but on some undetermined species of Dioscorea. The spores of the Cuban material resemble those of the type, which was on Dioscorea grandiflora from Brazil, but appear slightly thinner walled, and a little more coarsely verrucose. All the Stevens' collections agree with the Cuban material, except that no. 5948 does not appear to vary at all from the type collection. The variations noted seem unimportant. Pore characters could not be determined, but the arrangement is probably equatorial.

86. Uredo nigropunctata P. Henn. Hedwigia $35: 254 . \quad$ i8g6. ON ORChidaceae :

Bletia patula Hook., Maricao, April 3, 804a, 826.

The species occurs on phanerogamic specimens in the N. Y. Bot. Garden of the same host from Cuba, March, I903, Underwood \& Earle 929, and on Bletia purpurea (Lam.) DC. from Hayti, Aug., 1903, Geo. V. Nash 706, and from the Bahamas, March, 1907, L. J. K. Brace 70II, and Feb., I9I0, Small \& Carter 8876 .

87. Uredo Erythroxylonis Graz. Bull. Soc. Myc. Fr. 7 : i 53. I89I.

On ERythroxylonaceae:

Erythroxylon areolatum, L., Mona Island, Dec. 20, 21, $6148,6448$.

The species has been collected in Prov. Havana, Cuba on E. havanense Jacq. in 1904, by C. F. Baker 4127 (Barth. Fungi Columb. 2287), the host having recently been determined by $\mathrm{Mr}$. 
Percy Wilson of the N. Y. Bot. Garden. It was also collected in Prov. Pinar del Rio, Cuba, on a phanerogamic specimen of $E$. havanense, Dec., I9II, by Percy Wilson II 560 .

The spores of the two Porto Rican collections measure I6-20 by $2 \mathrm{I}-27 \mu$, and largely are cinnamon-brown above and paler in color below. Most collections of the rust seen by the writer, and especially those on the same host as the type, E. Coca, have larger spores, $18-23$ by $24-32 \mu$, which are concolorous. In a collection made by J. N. Rose 18916 , in Bolivia, Aug. I6, I9I4, only about half of the spores are paler below. In some sori taken from a phanerogamic specimen of E. areolatum 6449 , in the N. Y. Bot. Garden, with the same data as no. 6448 above, many spores measure quite as long as those found on E. Coca. It may be assumed, therefore, that variation in size and color of spores is incidental.

88. Uredo Hymenaeae Mayor, Mem. Soc. Neuch. Sci. 5: 585 . I9I3.

On Caesalpiniaceae:

Hymenaea Courbaril L., Joyuda, March 31, 962; Mayagüez, May 3, II57, Oct. 31, 3897, 390I; Añasco, Sept. 21, 3210, Oct. 12, 3575; Vega Baja, Nov. 5, 4324.

This rust was described from Colombian material on an undetermined species of Hymenaea. Dr. Stevens's fine set doubtless makes the second lot to be collected. The rust exhibits characteristics of the subfamily Raveneliatae, in the elongated spore with equatorial pores.

89. Uredo lutea sp. nov.

Uredinia hypophyllous, abundantly scattered or in small groups on discolored spots, pustular, $0.3-0.7 \mathrm{~mm}$. across, long covered by the brown overarching epidermis, finally sparingly pulverulent, subepidermal; paraphyses none; urediniospores pedicillate, irregularly ellipsoid or obovoid, I9-2I by $26-29 \mu$; wall cinnamonbrown, about $\mathrm{I} .5 \mu$ thick, moderately echinulate, the pores usually indistinct, 2 or rarely 3 , equatorial.

On Caesalpiniaceae:

Cassia quinquangulata L. C. Rich., without locality or date, 404bis; Maricao, April 4, 704; Jayome Alto, Dec. 3, 5653; Preston's ranch near Naguabo, Dec. 31, 6762 . 
This rust presents few salient features, either in the sorus or the spores. The host and the lack of any debarring characters would indicate that it belongs under Ravenelia. It does not, however, accord with any known species of that genus so far as can be ascertained.

90. Uredo Arachidis Lagerh. Tromsö Mus. Aarsh. i7 : 106. I894.

Uromyces Arachidis P. Henn. Hedwigia 35: 224. 1896. ON FABACEAE:

Arachis hypogea L., Dorado, Nov. 25, 5318, 5319.

The two collections by Stevens are the only ones from the West Indies known to the writer. The rust is probably not rare, however, as I have found at the N. Y. Bot. Garden that it occurs on a phanerogamic specimen of $A$. hypogea from Grenada, W. E. Broadway, Oct., 1905, and on one from Guadeloupe, Pére Duss 3581 , Dec., I894.

A species of Uromyces has been described for this host from Surinam by Hennings, but the type material is said by Sydow (Monog. Ured. 2: 346. I9I0) to show only urediniospores. A species of Puccinia on the same host was described by Spegazzini in 1884 (An. Soc. Ci. Arg. 17:90) no material of which has been seen. There is no mention of urediniospores, and the relationship with material in hand is problematical.

91. Uredo Cabreriana Kern \& Kellerm. Jour. Myc. I3: 25. I907.

On Fabaceae:

Erythrina glauca Willd., Bayamon, Feb. 23, 386, Feb. 20, 44I, June 23, 2498, without date, 4096.

Porto Rican collections have been made on the same host at Rio Piedras, by J. R. Johnston I099, and J. A. Stevenson 2345, and at Bayamon, Jani, I9I I, by E. D. W. Holway.

It has been collected on the same host in Cuba as part of a phanerogamic specimen, in 1906, by Abarca \& O’Donovan 2634, communicated by Percy Wilson.

The type collection came from Guatemala. The host of the 
type was determined by Capt. J. Donnell Smith as Buettneria lateralis, but after the Stevens' collections came to hand the original material was again submitted to Capt. Smith who found that through some error it had been wrongly reported, and was in fact Erythrina glauca. The Holway collection from Cuba was first said to be on E. micropteryx, which is clearly an error.

92. Uredo Cupheae P. Henn. Hedwigia 34: 99. 1895.

On Lythraceae:

Cuphea Parsonsia R. Br., Cabo Rojo, June I5, 2279.

This is the first collection of this rust in North America. The gross and microscopic appearance of the Porto Rican material agrees perfectly with that of the type, which was collected at Goyaz, Brazil by E. Ule 200I, on an undetermined species of Cuphea.

93. Uredo fallaciosa sp. nov.

Uredinia hypophyllous, irregularly gregarious on somewhat discolored spots, roundish, $0 . \mathrm{I}-0.5 \mathrm{~mm}$. across, tardily naked, pulverulent, fuscous; urediniospores ellipsoid or obovoid, I8-23 by 24-29 $\mu$; wall pale yellow or slightly fuscous, I-I.5 $\mu$ thick, moderately echinulate, the pores obscure.

On Rubiaceae:

Psychotria patens Sw., Maricao, April 3, 774 (type); Ponce, Nov. 8, $434 I$.

The uredinia are not abundant in these collections. The sori are not prominent on the leaf surfaces, merely making an inconspicuous roughening that attracts attention chiefly by the slight discoloration. The sori are subepidermal, without paraphyses, and have the aspect of forms belonging to species of Uromyces and Puccinia. Three rusts with uredinia have been described by Hennings from South America, but in the absence of material for examination it is not possible to say if any of them include the Porto Rican form.

94. Uredo sabiceicola sp. nov.

Uredinia largely hypophyllous, scattered singly or in groups of 2-5 on small discolored spots $0.5^{-1} \mathrm{~mm}$. across, round, small, $0.1-0.3 \mathrm{~mm}$. in diameter, dull cinnamon-brown, subepidermal; 
paraphyses peripheral, numerous, incurved, clavate, stout, Io-I2 by $19-23 \mu$, the wall colorless, thin, $0.5 \mu$, somewhat thickened on the outer curved part, I. $5-2 \mu$, smooth; urediniospores obovoid, I6-23 by $25-29 \mu$; wall golden-yellow, thin, I $\mu$, moderately verrucose-echinulate, the pores obscure.

\section{On Rubiaceae:}

Sabicea aspera Aubl., Mayagüez, May I, I047.

This distinctive rust with its conspicuous paraphyses is evidently not the same as Uredo Cephalanthi Arth., which is without paraphyses. There appears to be no other form known that is at all closely related.

\section{Uredo proximella sp. nov.}

Uredinia chiefly hypophyllous, crowded in groups $2-4 \mathrm{~mm}$. across, bullate, roundish or irregular, large, $0.3-0.9 \mathrm{~mm}$. across, tardily naked, cinnamon-brown, pulverulent, ruptured epidermis conspicuous as a partial membranous covering; urediniospores broadly ellipsoid or obovoid, I8-20 by $19-24 \mu$; wall cinnamonbrown, thin, I-I.5 $\mu$, closely and finely echinulate, the pores rather indistinct, $4-6$, scattered.

\section{On Cichoriaceae:}

Lactuca intybacea Jacq., Sabana Grande, March 30, $3{ }_{18}$.

In the characters of both sori and spores this species bears considerable resemblance to the uredinia of Puccinia hemisphaerica (Peck) Ellis \& Ev. It has been detected on specimens in the phanerogamic collection of the N. Y. Bot. Garden from St. Domingo, March, I9I3, Rose, Fitch \& Russell 40I5, and from Cuba, March, I909, N. L. Britton $216 I$.

96. Uredo Biocellata Arth. Bull. Torrey Club 33: 517. 1906. On Carduaceae:

Pluchea odorata (L.) Cass., Ponce, Dec. 4, 5393; Vega Baja, Feb. 22, 360a.

Pluchea purpurascens (Sw.) DC., Santurce, May 2I, I799; Cabo Rojo, Sept. 28, 3186; Mona Island, Dec. 20, 21, 6198.

The species was also found in the phanerogamic herbarium of the N. Y. Bot. Garden on P. odorata, collected at Guanica, P. R., Jan., I899, by C. F. Millspaugh $7 I 3$. 
In the same herbarium it occurs on $P$. purpurascens from St. Domingo, collected March I9I3, by Rose, Fitch \& Russell 4294. Heretofore the species has only been known from southern Florida.

97. Uredo vicina sp. nov.

Uredinia hypophyllous, scattered, round, $0.3-0.5 \mathrm{~mm}$. across, soon open, dark cinnamon-brown, pulverulent, ruptured epidermis evident; urediniospores globoid, often flattened above, $24-29 \mu$ in diameter; wall chestnut-brown, I.5-2 $\mu$ thick, closely echinulate, the pores 4 , equatorial.

ON CaRduaceae:

Wedelia lanceolata DC., Guanica, Feb. 3, 365, Feb. Io, 365 bis (type).

The spores of this species are entirely unlike the urediniospores of Uromyces pianhyensis, on another species of Wedelia, especially in size and in having decidedly thicker walls with more pores that are clearly evident.

98. Uredo Sparganophori P. Henn. Hedwigia 43: i6o. I904. ON CaRduaceae:

Struchium Sparganophorum (L.) Kuntze (Sparganophorum Vaillantii Gärt.), Mayagüez, April 29, 523, April 30, $9 I I$.

Although the leaves were well covered with uredinia, no trace of telia or aecia could be found. The same rust was detected in the phanerogamic collection of the N. Y. Bot. Garden on the same host from Green Island, Jamaica, March, I908, Wm. Harris 10254 .

99. Uredo Gymnogrammes P. Henn. Hedwigia 34:337. 1895. On Polypodiaceae:

Dryopteris Poiteana (Bory) Urban, Villa Alba, Jan. 3, 86. The same fungus was collected in Jamaica on Dryopteris patens (Sw.) Kuntze, May, 1903, by L. M. Underwood 2869, and in Cuba, on Pityrogramma calomelaena (L.) Link, March, I903, by E. W. D. Holway. 
Uredo superficialis (Speg.) Lagerh., a very similar fungus, was collected in Jamaica on Anemia hirsuta (L.) Sw., Feb., I903, by L. M. Underwood II

Both of these forms on ferns are to be included under the Uredinales with considerable doubt, on account of the form of the sorus. They need to be studied cytologically and also as to their development.

Ioo. Uredo Stevensiana sp. nov.

Uredinia chiefly epiphyllous, scattered or in small groups on discolored spots, elliptical, small, $0.2-0.5 \mathrm{~mm}$. long, brownishyellow, rather tardily naked by a longitudinal rupture of the epidermis; paraphyses numerous, chiefly peripheral, erect or incurved, clavate, IO-I 5 by $29-50 \mu$, the wall colorless, thin, about I $\mu$, somewhat thicker above, $2-4 \mu$; urediniospores ellipsoid, I6-2I by $23-27 \mu$; wall pale-yellow or colorless, thin, I-I. $5 \mu$, closely and rather prominently echinulate, the pores indistinct.

On Poaceae:

Axonophus compressus (Sw.) Beauv. (Paspalum compressum Rasp.), Mayagüez, Jan. 9, I9I3, 237, Feb. 8, 280, April 30, 923.

Paspalum Humboldtianum Flügge, Cuernavaca, Mex., Sept. 28, I899, E. W. D. Holway 35I0 (type).

Paspalum paniculatum L., Vega Baja, Feb. 22, 373.

Paspalum (? Helleri Nash), Mayagüez, April 30, 932.

Paspalum plicatulum Michx., Mayagüez, April 30, 943.

This grass rust differs from Uredo paspalicola, which it closely resembles in general appearance, by the presence of numerous paraphyses and the somewhat smaller spores. The collections made by Dr. Stevens are the only ones seen or known from the West Indies, or in fact from any locality, except the one collected by Holway from central Mexico. The Mexican collection is ample, the rust well displayed and free from parasites, and is therefore chosen for the type of the species. The Stevens' collections are less ample, and the rust much parasitized. But it was the varied material supplied by Dr. Stevens that made it possible to delimit the species, and to him rightly belongs the honor implied in the proposed specific name. 
IOI. Uredo rubescens sp. nov.

Uredinia hypophyllous, irregularly grouped on indefinite pale spots, round, small, $0.2-0.4 \mathrm{~mm}$. across, soon naked as if by a central pore, surrounding epidermis scarcely noticeable except for a reddish coloration, subepidermal; paraphyses peripheral, cylindrical, hyphoid, incurved, scarcely rising above the sporemass, the wall colorless and smooth; urediniospores ellipsoid, I8-I9 by $25-28 \mu$; wall pale cinnamon-brown, I.5 $\mu$, rather closely and strongly echinulate, the pores obscure.

\section{On Moraceae:}

Dorstenia Contrajerva L., Camuy, Nov. 22, $50 I I$.

A well marked form. Although the paraphyses are not readily found except by sectioning, yet they are indicated under a hand lens as a pale circle bounding the sorus. The spores either have very short pedicels or are formed in chains, of which only one spore matures at a time. Even the best sections do not decide the matter, but it must be left to be worked out from a study of the cytological development.

\section{I02. Uredo Bixae sp. nov.}

Uredinia epiphyllous, numerous, scattered singly or in groups of two to four on small purple spots, very small, about o.I $\mathrm{mm}$. across, soon uncovered, ruptured epidermis inconspicuous, the paraphyses showing as a whitish circle, subepidermal; paraphyses peripheral, numerous, incurved, rising but little above the surface of the leaf, clavate-cylindric, 9-10 by $27-35 \mu$, the walls colorless, smooth, less than I $\mu$ inside and $2-5 \mu$ outside; urediniospores obovoid, I6-23 by $26-37 \mu$; wall nearly colorless, thin, I $\mu$ or less, closely and finely echinulate, the pores obscure.

\section{ON BiXACEAE:}

Bixa Orellana L., Adjuntas, March 2, 462.

The host is a native of tropical America, but has been cultivated and become wild in tropical regions throughout the world. It supplies the coloring matter of commerce called annatto, much used in butter.

The sori are very small, numerous and deep-seated, but in the specimen examined, they are much parasitized and the spores few. 
I03. Uredo Capituliformis P. Henn. Hedwigia 34: 97. I895. Ravenelia capituliformis P. Henn. Hedwigia 43: I60. 1904. ON EUpHORBIACEAE:

Alchornea latifolia Sw., Luguillo forest, Dec. 2, 5437 ; Preston's ranch near Naguabo, Dec. 31, 6669.

This is the first record of the occurrence of this species in North America. The type collection was made by E. Ule 3060, at Goyaz, Brazil, and shows an abundance of the very peculiar uredinial sori. These sori arise from under the cuticle from a minute hymenial layer. They expand into a globular, brown capitulum, seated lightly on the surface of the leaf and composed of incurved, thick-walled, dark-brown paraphyses, holding a small number of spores. The appearance under a low magnifying power is much like that of the fruit of some Erisyphe or other Perisporiaceous fungus. The spores are equally remarkable with the sori in possessing four bulging protuberances in the upper half of the generally obovoid spore, and a similar apical protuberance. The wall of the spore is cinnamon-brown, I-I.5 $\mu$ thick, and closely echinulate. The pores can not be located.

In these characters the rust collected by Stevens in Porto Rico agrees perfectly. In addition, however, both the Stevens' collections show well formed pycnia and aecia. The pycnia are conspicuous, epiphyllous, in small groups, mamilliform, subcuticular but depressing or absorbing the epidermal cells, IooI65 $\mu$ across; ostiolar filaments apparently wanting. The aecia are amphigenous, gregarious, more abundant on the upper surface of the leaf surrounding the pycnia. They are subepidermal, with the adjoining epidermal cells greatly elongated to form a cone about the mouth of the aecium. A persistent peridium barely protrudes beyond the leaf-surface, and the structure can not be determined with dried material. The aeciospores are catenulate with intercallary cells. They closely resemble the remarkable urediniospores in form, color and markings, but the echinulation, if such it is to be called, is considerably coarser. The finest points appear like those on the urediniospores. The points are, however, mostly conspicuously hyaline, acute warts, although their bases are too narrow for them to be unreservedly called verrucose. 
The peculiar appearance of the uredinia led Hennings to place this rust in the genus Ravenelia, but the discovery of the aecia makes this more ill advised than at first. When the telia are found, it is more likely to constitute a new genus, or to belong to a little known one.

In the phanerogamic collection at the N. Y. Bot. Garden, pycnia and aecia were found on A. latifolia from island of Tortola, I9I3, J. A. Shafer II48.

I04. Uredo Gounaniae Ellis \& Kelsey, Bull. Torrey Club 24: 209. I897.

On Frangulaceae (Rhamnaceae) :

Gouania lupuloides (L.) Urban ( $G$. domingensis L.), Jajone Alto, Dec. 3, 5685; Aguadillo, Nov. 22, 570I; San German, Nov. 8, $579 I$.

Gouania polygama (Jacq.) Urban (G. tomentosa Jacq.), Guanica, Feb. 3, 328 .

This form is distinguished from the uredinia of Puccinia Gouaniae Holw. by the reniform spores with one lateral pore. Whether this morphological difference indicates a true specific distinction, or only a racial one, is not likely to be decided until teliospores of this form are found, and possibly not until the full life cycle of both forms is known.

The collections by Dr. Stevens are the only ones known to the writer except the type collection made by A. E. Ricksecker in St. Croix, Jan., I896.

I05. Uredo Commelyneae Kalchbr. Grevillea ir: $24 . \quad$ i882. On Commelinaceae:

Commelina virginica L. (C. elegans H. B. K.), Coamo Springs, Nov. I3, 3981 .

So far as the writer knows, this species of rust has heretofore only been known from the type collection, made at Port Natal, South Africa. Through the kindness of the Director of the Kew Gardens, I have been able to study a portion of the original material from the Kew Herbarium, and find that it agrees perfectly with the material collected by Dr. Stevens. Hoping to 
secure further knowledge of so rare a tropical form, I appealed to $\mathrm{Mr}$. Percy Wilson to look at specimens in the phanerogamic herbarium at the N. Y. Bot. Garden. Mr. Wilson found three collections with an abundance of the rust. They are all three on C. virginica, two from Porto Rico, Arecibo, Jan. 27, 1899, Mr. \& Mrs. A. A. Heller 357, Sabana Llana, Nov. \& Dec., I899, George P. Goll I64, and one from St. Thomas, Feb., I887, Eggers.

This species differs in a very marked way from the uredinia of Uromyces Commelinae, in having smaller and nearly colorless spores with thin walls, and especially in possessing a paraphysoid peridium opening by a central pore, similar to that described under Uredo concors.

io6. Uredo Aeschynomenis Arth. Bot. Gaz. 39: 392. 1905.

Physopella (?) Aeschynomenis Arth. N. Am. Flora 7: I04. I907.

ON FABAceae:

Aeschynomene americana L., Mayagüez, Oct. 31, 3945; Ponce, Nov. 8, 4356; Maricao, Nov. I8, 4798; Rosario, Nov. I4, 4842; Utuado, Nov. 8, 458 $1 a b$; Aguada, Nov. 22,5074 .

The species was described from Mexican material. A collection from Caracas, Venezuela, was subsequenlty communicated to the writer by W. G. Farlow. It is also reported by Mayor (Mém. Soc. Neuch. Sci. 5: 587. I9I3) from Colombia. Mayor also reports the species from the same region on $A$. sensitiva Sw.

The uredinia only are known. They possess a strongly developed pseudoperidium composed of imbricated paraphyses, a character not consistent with typical species of Physopella. The species is, therefore, listed here under Uredo.

\section{I07. Uredo concors sp. nov.}

Uredinia hypophyllous, in small groups on discolored usually reddish spots, mammillose, small, $0 . \mathrm{I}-0.3 \mathrm{~mm}$. across, finally opening by a small central pore; paraphyses united by their bases and internally imbricated to form a pseudoperidium, colorless to golden-brown, the free ends clavate, with moderately thick and 
smooth wall; urediniospores ellipsoid or somewhat obovoid, I $5^{-2}$ I by I9- $28 \mu$; wall nearly or quite colorless, thin, I. $5 \mu$, closely and finely verrucose-echinulate, the pores obscure.

ON FABACEAE:

Dolichos Lablab L., Jayuya, Dec. I7, 6042 (type).

Teramnus uncinatus (L.) Sw., Jayuya, Dec. I7, 5998.

The Uredo Teramni Mayor differs greatly from the above species in having a sorus without paraphyses, and in having globose, 2-pored spores.

I08. Uredo jatrophicola sp. nov.

Uredinia hypophyllous, crowded on slightly discolored spots or evenly scattered, bullate-conical, small, o.I-0.3 mm. in diameter, long covered by the overarching epidermis, opening by a central pore that gradually enlarges; peridium paraphysoid, the paraphyses clavate with the slender stalks firmly united into an enclosing wall, and with the heads, 9-12 $\mu$ broad, imbricately projecting into the cavity of the sorus, the largest ones at the orifice, the wall smooth, about I $\mu$ thick and colorless below, about $3-7 \mu$ and tinted above; urediniospores ellipsoid or obovoid-ellipsoid, I6-20 by $24-29 \mu$; wall very pale yellow or colorless, thin, I-I.5 $\mu$, rather closely and finely echinulate; pores not discernible.

On Euphorbiaceae:

Jatropha Curcas L., Hormigueros, Jan. I4, 220 (type). Jatropha gossypifolia L., San German, Dec. 8, 4II3, 4790;

Guayama, Dec. 4, 540I; Guayanilli, Nov. I3, 5866bis.

The species has also been detected on phanerogamic specimens: on J. Curcas, St. Domingo, March, 1913, Rose, Fitch \& Russell 4064; on J. gossypifolia, Cuba, April, I903, J. A. Shafer 86, March, I910, Britton \& Wilson 5549, St. Croix, Feb., I9I3, Rose, Fitch \& Russell 3204.

The paraphysoid peridium and pale spores make a marked distinction between this and other known rusts on Euphoriaceous hosts. Small subepidermal sori were found on the two Cuban specimens that appeared like compact, lens-shaped telia, beneath the epidermis, with small, smooth, thin-walled spores, but they were very few and uncertain, and may have been only young uredinia. 


\section{$2 \mathrm{BHL}$ Biodiversity Heritage Library}

Arthur, Joseph Charles. 1915. "Uredinales of Porto Rico based on collections by F.L. Stevens." Mycologia 7(6), 315-332.

View This Item Online: https://www.biodiversitylibrary.org/item/192168

Permalink: https://www.biodiversitylibrary.org/partpdf/246800

\section{Holding Institution}

New York Botanical Garden, LuEsther T. Mertz Library

\section{Sponsored by}

BHL-SIL-FEDLINK

\section{Copyright \& Reuse}

Copyright Status: Public domain. The BHL considers that this work is no longer under copyright protection.

This document was created from content at the Biodiversity Heritage Library, the world's largest open access digital library for biodiversity literature and archives. Visit BHL at https://www.biodiversitylibrary.org. 